\title{
COMMENTS
}

\section{COST JUSTIFICATION UNDER THE ROBINSON-PATMAN ACT}

The recent decision by the Court of Appeals for the District of Columbia in Simplicity Patterns Co. v. $F T C^{1}$ represents a novel judicial approach to certain sections of the Robinson-Patman Act. ${ }^{2}$ Simplicity Patterns Co. was charged with violating Section $2(\mathrm{e})^{3}$ of the Act by furnshing free catalogs and storage cabinets to chain-store purchasers of its patterns, while charging smaller customers for these facilities. The Federal Trade Commission held that no weight could be given to a cost justification for this differential treatment of customers. Reversing the FTC's holding, ${ }^{4}$ the Court of Appeals ${ }^{5}$ relied on Section 2(b) ${ }^{6}$ which provides that the burden of rebutting a prima facie case of discrimination in price or facilities furnished, by showing justification, is upon the person charged. ${ }^{7}$

The existence of a statutory section allocating the burden of proof in a showing of justification, the court reasoned, clearly presupposes the existence of a justification. ${ }^{8}$ Since Section 2(b) is applicable to Section 2(e) proceedings because it refers to discrimination in furnishing services or facilities, the court concluded that Congress intended some justification to be available against Section 2(e) charges. Finding no justification provided in Section 2(e) itself, ${ }^{9}$

1258 F.2d 673 (App.D.C., 1958), cert. granted, Docket No. 406, 27 U.S. Law Week 3159 (1958); also Docket No. 447, see note 50 infra.

249 Stat. 1526 (1936), 15 U.S.C.A. $\$ 13$ (1952).

${ }^{3}$ Section 2(e) provides that it shall be unlawful for any person "to discriminate ... by ... furnishing... any services or facilities... upon terms not accorded to all purchasers on proportionally equal terms." Id., at $\$ 13(\mathrm{e})$.

4 The court upheld the FTC ruling that no showing of competitive injury was necessary for a prima facie case of violation of Section 2(e). See note 50 infra.

${ }^{5}$ In dissent, Judge Washington argued that Section $2(\mathrm{~b})$ added nothing substantive to Section 2(e) and that, therefore, cost justification is not a defense in Section 2(e) actions. Simplicity Patterns Co. v. FTC, 258 F.2d 673, 684 (App. D.C., 1958).

6 "Upon proof being made, at any hearing on a complaint under this section, that there has been discrimination in price or services or facilities furnished, the burden of rebutting the prima-facie case thus made by showing justification shall be upon the person charged with a violation of this section, and unless justification shall be affirmatively shown, the Commission is authorized to issue an order terminating the discrimination: Provided, however, That nothing... shall prevent a seller rebutting the prima-facie case thus made by showing that his lower price or the furnishing of services of facilities to any purchaser or purchasers was made in good faith to meet an equally low price of a competitor, or the services or facilities furnished by a competitor." 49 Stat. 1526 (1936), 15 U.S.C.A. \$13(b) (1952).

${ }^{7}$ Simplicity Patterns Co. v. FTC, 258 F.2d 673, 679 (App. D.C., 1958).

8 Ibid.

Id., at 681. 
and finding the "meeting competition" proviso of Section 2(b) inapplicable to the facts of the Simplicity case, ${ }^{10}$ the court decided that "the justification to be shown under the first clause of Section 2(b) as to a Section 2(e) charge of discrimination... was to depend upon the facts in a particular case."11 Without further explanation, the court stated "[t]hat the term [justification] may include a 'cost justification' which Simplicity desired to establish seems clear enough."12

The result reached by the Court of Appeals is in conformity with the suggestions of commentators. ${ }^{13}$ Although Section 2(e) does not refer to cost justification, Section 2(a), which prohibits discrimination in price, ${ }^{14}$ provides that differentials in treatment of customers may be justified by differentials in the cost of selling to those customers. ${ }^{15}$ Commentators have argued that the cost justification provision in Section 2(a), together with the Section 2(a) requirement for a prima facie violation of injury to competition,,$^{16}$ should be read into Section 2(c), (d) and (e) of the Act to prevent "disparity in the statutory consequences which attach to economically equivalent business practices."17

The courts, however, have generally resisted any attempt to apply the limitations of Section 2(a) to other subsections..$^{18}$ In Biddle Purchasing Co. v. FTC, ${ }^{19}$ the Second Circuit held that the Section 2(a) requirement of injury to competition was not a requirement for a violation of Section 2(c).$^{20}$ Reaching

${ }^{10} \mathrm{Id}$. , at 679.

${ }^{11}$ Id., at 681 ; see note 50 infra.

12 Id., at 681.

${ }^{13}$ See Report of the Attorney General's National Committee to Study the Anti-trust Laws 191 (1955) (subsequently referred to as the Attorney General's Report); Austin, Price Discrimination and Related Problems under the Robinson-Patman Act 116 (1952).

14 Section 2(a) provides that "[i]t shall be unlawful ... to discriminate in price between different purchasers of commodities of like grade and quality ... where the effect of such discrimination may be substantially to lessen competition or tend to create a monopoly in any line of commerce, or to injure, destroy or prevent competition with any person who either grants or knowlngly receives the benefit of such discrimination, or either of them...." 49 Stat. 1526 (1936), 15 U.S.C.A. \$13(a) (1952).

15 "Provided, that nothing... shall prevent differentials which make only due allowance for differences in the cost of manufacture, sale, or delivery resulting from the differing methods of quantities in which such commodities are to such purchasers sold or delivered...." Ibid.

${ }^{16}$ See note 14 supra.

${ }^{17}$ Attorney General's Report 191 (1955).

${ }^{18}$ But see National Nut Co. v. Kelling Nut Co., 61 F.Supp. 76, 82 (N.D. Ill., 1945), implying that where injury to competition has not been shown, no violation of Section 2(e) has been established. For a dictum that cost justification is a defense in Section 2(e) actions, see Empire Rayon Yarn Co. v. American Viscose Corp., 160 F.Supp. 334 (S.D.N.Y., 1958).

1996 F.2d 687 (C.A.2d, 1938), cert. denied 305 U.S. 634 (1938). Accord: Webb-Crawford Co. v. FTC, 109 F.2d 268 (C.A.5th, 1940), cert. denied 310 U.S. 638 (1940).

${ }^{20}$ Section 2(c) provides that "[i]t shall be unlawful for any person ... to pay or grant, or to receive or accept, anything of value as a commission, brokerage, or other compensation, 
the same conclusion, the Fourth Circuit in Oliver Bros., Inc. v. FTC ${ }^{21}$ stated that it saw no reason to read into "[(c), (d) and (e)] the limitations contained in Section 2(a) having relation to price discrimination" since the trade practices dealt with in (c), (d) and (e) were prohibited "because of their tendency to lessen competition ... without regard to a particular case."22 The same reasoning led the Third Circuit to reject cost justification as a defense to Section 2(c) charges in Great Atlantic \&o Pacific Tea Co. v FTC. ${ }^{23}$ And, in Elizabeth Arden, Inc. v. FTC, ${ }^{24}$ the Second Circuit held that the requirement of injury to competition was inapplicable to Section 2(e), finding no reason to read Section 2(a) limitations into Section 2(e) ${ }^{25}$

\section{I}

Although reliance in the Simplicity case on the first clause of Section 2(b) instead of Section 2(a) to hold cost justification a defense to Section 2(e) charges avoids direct conflict with prior cases, ${ }^{26}$ the Simplicity rationale appears questionable. The first clause of Section 2(b) appears to be, and has been interpreted by the Supreme Court, as purely procedural. ${ }^{27}$ Certainly, it does not, itself, provide that cost justification is available in a Section 2(e) proceeding. Nor did the court in the Simplicity case find in Section 2(e) alone any indication that cost justification was available as a defense. ${ }^{28}$ It is difficult to see how the two sections, neither of which provide for a defense, can be read together as establishing that defense.

In any event, if the procedural clause of Section 2(b), with its reference

or any allowance or discount in lieu thereof, except for services rendered in connection with the sale ... either to the other party to such transaction or to an agent... where such [agent] is acting in fact for ... or is subject to the direct or indirect control, of any party to such transaction other than the person by whom such compensation is so granted or paid." 49 Stat. 1526 (1936), 15 U.S.C.A. \$13(c) (1952).

21102 F.2d 763 (C.A.4th, 1939).

22 Id., at 767. See also Southgate Brokerage Co. v. FTC, 150 F.2d 607 (C.A.4th, 1945), cert. denied 326 U.S. 774 (1945).

${ }^{23} 106$ F.2d 667 (C.A.3d, 1939), cert. denied 308 U.S. 625 (1940).

24156 F.2d 132 (C.A.2d, 1946), cert. denied 331 U.S. 806 (1947). Accord: Corn Products Refining Co. v. FTC, 144 F.2d 211 (C.A.7th, 1944), aff'd 324 U.S. 726 (1945).

25 "We see no reason why the limitations contained in (a), or their equivalent, should be read into (e)." 156 F.2d 132, 135 (C.A.2d, 1946).

${ }^{26}$ The court in the Simplicity case explicitly refused to read into Section 2(e) the limitations contained in Section 2(a). Simplicity Patterns Co. v. FTC, 258 F.2d 673, 681 (App.D.C., 1958).

27 "Throughout this opinion a reference to $2(\mathrm{~b})$ is to the procedural language preceding the proviso...." Automatic Canteen Co. v. FTC, 346 U.S. 61, 75 n. 17 (1953). "We think we must read the infelicitous language of 2 (b) as enacting what we take to be its purpose, that of making it clear that ordinary rules of evidence were to apply in Robinson-Patman Act proceedings." Id., at 78.

${ }^{28}$ Simplicity Patterns Co. v. FTC, 258 F.2d 673, 681 (App.D.C., 1958). 
to 2(e), ${ }^{29}$ clearly presupposes a defense to a 2(e) charge, no reason appears why the "meeting-competition" defense provided in Section 2(b) ${ }^{30}$ and clearly applicable to Section $2(\mathrm{e})$ proceedings, ${ }^{31}$ is not sufficient to avoid finding the 2(b) reference to 2(e) meaningless. In addition, another justification to Section 2(e) charges might be found in that section itself. The dissent in the Simplicity case argued that a showing that facilities were furnished on proportionally equal terms justifies discrimination in facilities furnished..$^{32}$ The majority's rejection of this argument, on the grounds that where terms are proportionally equal there is no discrimination in the first place (and thus justification is unnecessary $)^{33}$ does not seem wholly satisfactory. The question is whether or not a prima facie case of violation of Section 2(e) can be made out without showing that terms were disproportional. If this is the case, and if the defendant then has the burden of showing that terms were proportionally equal, the "proportionally equal" phrase in 2(e) would seem to provide a justification within the meaning of Section 2(b). Since the "proportionally equal" phrase has been held to provide a justification in this sense in Section 2(d) actions, it seems likely that a similar result would be appropriate under Section $2(\mathrm{e}) .^{34}$

Thus, it is clear that at least one, and possibly two, justifications within the meaning of Section 2(b) are available in Section 2(e) proceedings. As a result, the rationale developed in the Simplicity case appears untenable, since it rests on the premise that defenses must be created for 2(e) proceedings to avoid rendering the first clause of 2(b) meaningless in its reference to 2(e).

A second difficulty with the Simplicity rationale is that it may lead to inconsistent results. Since cost justification is available as a defense to Section 2(e) charges under this rationale only because Section 2(b)'s reference to 2(e) would otherwise be meaningless, it would appear that cost justification would not be available under a section to which 2(b) makes no reference. Such a section, for example, is $2(\mathrm{~d})^{35}$ which prohibits disproportionate pay-

${ }^{29}$ See note 6 supra. $\quad{ }^{30}$ See note 6 supra. See note 6 supra.

${ }^{32}$ Simplicity Patterns Co. v. FTC, 258 F.2d 673, 684 (App.D.C., 1958).

${ }^{33}$ Id., at 681.

${ }^{34}$ In State Wholesale Groc. v. Great Atlantic \& Pacific Tea Co., 258 F.2d 831 (C.A.7th, 1958), it was held that the defendant has the burden, in a Section 2(d) case of showing proportionality in order to overcome a prima facie case of violation. Although the court relied on language in Section 2(d) which is not found in Section 2(e), it seems unlikely that Congress intended the FTC to bear the burden in a 2(d) case, but not in a 2(e) case. That defendants have this burden seems desirable, in both 2(d) and 2(e) actions, in view of the fact that defendants would presumably have easier access to the relevant evidence than would the FTC. But see Austin, op. cit. supra note 13, at 142.

${ }^{35}$ Although Section 2(b) makes reference to furnishing of services or facilities, dealt with in section 2(e), no mention is made of payments for services, dealt with in Section 2(d). As a result, in a case involving the "meeting competition" defense provided in Section 2(b), it was held that Section 2(b) is not applicable to Section 2(d). Henry Rosenfeld, Inc., CCH Trade Reg. Rep. ๆ26,068 (FTC, 1956). 
ments for services. Yet it is difficult to see any reason why Congress should choose to permit cost justification as a defense to the disproportionate furnishing of services, while not permitting it as a defense to disproportionate payment for services. ${ }^{36}$

II

Assuming, arguendo, that it is desirable that cost justification be a defense to a Section 2(e) charge, there are two possible constructions of the Act by which that result could be achieved aside from that given in the Simplicity case.

The Cost Justification Proviso. It can be argued that the proviso in Section 2(a) under which differentials are lawful when they do not exceed difference in cost due to method or quantity of sale or delivery, should be applicable to Section 2(d) and (e). The proviso is not by its terms limited to Section 2(a) since it refers to "differentials," not "price differentials." 37

While it has generally been assumed that prior cases have foreclosed such an argument, ${ }^{38}$ this does not appear to be true. The cases which have held the requirement of injury to competition-an element necessary to sustain a Section 2(a) charge-inapplicable to Section 2(c) and (e), rest on the assumption that Congress decided that the activities dealt with by those subsections inevitably tended to lessen competition. ${ }^{39}$ This interpretation does not appear inconsistent with the policy expressed in Section 2(a) - so long as the activities involved are not cost-justified. However, to hold that discrimination, even when cost-justified, inevitably tends to injure competition, necessitates an assumption that the type of competition to be protected under the Act is competition which would be injured when efficient competitors acquire savings from their efficiency. Section 2(a), with its provision for cost-justified differentials, indicates that Congress did not intend to protect this type of competition. And there is no apparent reason why Congress should desire to protect this type of competition in the 2(d) and (e) situations and not in the 2(a) situation.

Nor does Great-Atlantic \& Pacific Tea Co. v. FTC, ${ }^{40}$ which held cost justi-

${ }^{36}$ Under the Simplicity rationale, it also appears possible that cost justification would not be a defense in treble damage suits for injuries due to discriminations in services furnished, provided for in 26 Stat. 210 (1890), as amended, 15 U.S.C.A. \$15 (1952). Since Section 2(b) appears limited by its terms to proceedings brought by the FTC, it might be argued that in a treble damage action, no reliance could be placed on Section 2(b). Since Section 2(e), standing alone, does not provide the cost justification defense, the defense would not be available. On the other hand, however, it could be argued that the existence of Section 2(b) in this context is necessary only to point out the intent of Congress that cost justification be available in Section 2(e) actions. Application of Section 2(b) to the particular case involving Section 2(e) would therefore not be necessary in order for the defense to be available.

${ }^{37}$ See note 15 supra.

${ }^{38}$ See, e.g., Austin, op. cit. supra note 13, at 116.

${ }^{39}$ E.g., Oliver Bros., Inc. v. FTC, 102 F.2d 763, 767 (C.A.4th, 1939); Elizabeth Arden v. FTC, 156 F.2d 132, 135 (C.A.2d, 1946).

${ }^{40}$ Great Atlantic \& Pacific Tea Co. v. FTC, 106 F.2d 667 (C.A.3d, 1939). 
fication inapplicable to Section 2(c), necessarily lead to the conclusion that the cost-defense proviso of Section 2(a) is not applicable to any other subsection. The defense offered in the $A \& P$ case was that the seller had received cost savings because the use of a broker was unnecessary. ${ }^{41}$ Had this justification for brokerage payments been accepted, Section 2(c) would have been rendered meaningless since its prime purpose was to prohibit brokerage payments between buyers and sellers when no broker was involved. ${ }^{42}$ Moreover, Section 2(c) prohibits, not differentials in brokerage payments, but all brokerage payments by a party to a sale to the other party or his agents. ${ }^{43}$ Section 2(d) and (e), on the other hand, prohibit discrimination in services or disproportionate payments for services, but not all payments for, or fumishing of, services. As a result, the cost-justified-differentials proviso could by its terms apply to (d) and (e), but not to (c). While no such distinction was made in the $A \& P$ case, the court there assumed that the cost justification question was decided in the "injury-to-competition" cases. ${ }^{44}$ Given the difference in the impact of cost justification on 2(c) as opposed to (d) and (e), it does not seem necessary to extend this over-simplification of the cost-justification problem to Section 2(d) and (e).

The "Proportionally Equal" Requirement. An alternative construction of the Act which would provide cost justification for Section 2(d) and (e) violations turns on the term "proportionally equal," found in both subsections. Neither subsection is violated when differentials occur, so long as the payments are made, or the services are furnished, on "proportionally equal" terms. The Act does not indicate what the differentials must be proportional to, nor has the FTC set forth exclusive criteria. ${ }^{45} \mathrm{~A}$ seller is allowed to provide to buyers a set dollar allowance per unit bought, provided that each buyer performs a certain promotional service. ${ }^{46}$ In effect, the seller pays different amounts for identical service, the amount varying with the quantity bought. Similarly, a seller may provide promotional services to buyers, the value of the services to be a uniform percentage of each buyer's volume. ${ }^{47}$ Again the value received by each buyer would vary with the quantity bought.

Similarly, where one of two buyers who purchase the same quantity makes his purchases in such a way that the cost of selling to him is less to the seller than the cost of selling to the other, it could be argued that the "proportionally

4 Id., at 669.

42 Oliver Bros., Inc. v. FTC, 102 F.2d 763, 769 (C.A.4th, 1939).

${ }^{43}$ Section 2 (c) is set forth in note 20 supra.

44 "This precise question was raised in the Biddle case." Great Atlantic \& Pacific Tea Co. v. FTC, 106 F.2d 667, 676 (C.A.3d, 1939).

${ }^{45}$ See Austin, op. cit. supra note 13 , at 132. For general rules developed by the FTC, see the Attorney General's Report 189 (1955).

${ }^{46}$ Ibid.

47 Ibid. 
equal" requirement should permit differentials in service or payments proportional to the differences in cost. No reason for excluding the idea "proportional to cost differences" from the term "proportionally equal" appears, and cost of 'sales is an important factor-perhaps a major reason why quantity is important. Under this approach services would be furnished or payments made on "proportionally equal" terms when a buyer is furnished services, or payments for services, of a value equal to the amount by which the costs of selling to that buyer are less than the cost of selling to another. ${ }^{48}$

\section{III}

Use of the "proportionally equal" construction or the cost-justification proviso would appear preferable to the construction developed in the Simplicity case. Both have the virtue of leading to consistent treatment of the companion ${ }^{49}$ subsections, (d) and (e), and neither would require the fundamental change in the statute of finding defenses on a case-to-case basis. ${ }^{50}$ However, there remains the more basic question of whether it would be desirable to interpret the statute so as to make cost differentials a defense under Section 2(d) and (e).

Judicial consideration of the applicability of cost justification to Section 2(d) and (e) must consider the fact that Congress was concerned with the possibility of abuse present in advertising services and allowances as well as in brokerage payments. ${ }^{51}$ And in discussions of the House and Senate bills prior to passage of the statute, Section 2(d) and (e) were consistently interpreted

48 Under this interpretation the purchaser whose methods cause the highest cost of sales to the seller would get no services. It might thus be argued that the "proportional to cost savings" interpretation is contra to that found in State Wholesale Groc. v. Great Atlantic \& Pacific Tea Co., 258 F.2d 831 (C.A.7th, 1958), in which it was pointed out that services which are not capable of being proportionalized, so that each customer can receive some services, are not "proportionately equal." It seems clear, however, that it was the services, not the criterion for proportionality, which was objected to in that case. When the criterion is volume of sales, one must have some volume to receive services. Similarly, when the criterion is cost savings, one must produce cost savings to the seller in order to receive services.

${ }^{49}$ See State Wholesale Groc. v. Great Atlantic \& Pacific Tea Co., 154 F.Supp. 471, 474 (N.D. Ill., 1958); the Attorney General's Report 189 (1955); Austin, op. cit. supra note 13, at 115 .

${ }^{50}$ The effect on the interpretation of Section 2(e) of the "case-to-case approach" is indicated by footnote 13 of the opinion. Simplicity Patterns Co. v. FTC, 258 F.2d 673, 681 n. 13 (App. D.C., 1958). This expression of Judge Burger's view that only differentials which actually injure competition are prohibited raises the possibility of a showing of absence of injury to competition as a defense to a prima facie case of violation of Section 2(e). The Supreme Court has granted certiorari on the question of whether or not a positive showing of absence of competitive injury precludes establishment of a prima facie case. Docket No. 447, 27 U.S. Law Week 3160 (1958). It could be argued that defenses other than cost justification and absence of competitive injury could be available under the Simplicity rationale, but Congressional intent to leave to courts the creation of defenses not found anywhere in the statute does not seem likely.

51 "The existing evil at which this part of the bill is aimed is, of course, the grant of discriminations under the guise of payments for advertising and promotional services..." 80 Cong. Rec. 9418 (1936). See also H.R. Rep. No. 2287, 74th Cong. 2d Sess. 15-6 (1936). 
as prohibiting payments for, or the furnishing of, services unless they were available to all on proportionally equal terms; there was no mention of a cost exception. ${ }^{52}$ The effect of a cost defense was several times outlined at length but was spoken of only as justifying price differentials. ${ }^{53}$ The inference would seem to be that differentials other than in price were intended to be prohibited unless proportionally equal in terms of something other than cost.

This inference might appear strengthened by a difference in effect between differentials under Section 2(d) and (e) and differentials under Section 2(a). It could be argued that the objection to differentials in services furnished and in payments for services is that both allow a seller to charge, in effect, different prices to different buyers while appearing to charge the same price. Thus the object of the two subsections could be said to be that of forcing differentials out into the open-into price-regardless of cost justification or of injury to competition. Such an approach to Section 2(c) was taken in the Biddle case ${ }^{54}$ in which injury to competition was rejected as a requirement of Section 2(c).

Moreover, a flat prohibition of disproportional differentials under Section 2(d) and (e) could be defended on the basis that bona fide cost savings could always be passed on to customers by price differentials. ${ }^{55}$ It could also be argued that the judgment to provide services to a buyer would always be based on the fact that such a program appeared to be of value to the seller, and not on the fact that the expenditure might be justified because of the relatively low cost of sales to that buyer. Cost justification might thus be said to be likely to benefit only those whose intent was to violate subsections (d) or (e). As a result, the approach to Section 2(c) found in the Biddle case ${ }^{56}$ might appear appropriate for Section 2(d) and (e).

However, the Biddle 57 approach does not appear applicable to Section 2 (d) and (e). Since the two subsections, unlike (c), allow differentials, ${ }^{58}$ it seems difficult to see how their objective could be to get differentials out into the open in the sense of restricting differentials to price. Nor is it clear that the

52 See H.R. Rep. No. 2287, 74th Cong. 2d Sess. 16 (1936); Sen. Rep. No. 1502, 74th Cong. 2d Sess. 7 (1936); H.R. Rep. No. 2951, 74th Cong. 2d Sess. 7 (1936).

${ }^{53}$ See, e.g. 80 Cong. Rec. 9417 (1936) where, in an explanation of the way cost justification was expected to be used, the phrase "price differential" is repeatedly used to describe what could be cost justified.

${ }^{54}$ Biddle Purchasing Co. v. FTC, 96 F.2d 687 (C.A.2d, 1938), cert. denied 305 U.S. 634 (1938).

${ }^{65}$ See note 15 supra.

${ }^{56}$ Biddle Purchasing Co. v. FTC, 96 F.2d 687 (C.A.2d, 1938), cert. denied 305 U.S. 634 (1938).

${ }^{57}$ Ibid.

38 Differentials are permitted under Sections (d) and (e) so long as they are "proportionally equal." See note 3 supra. A policy of simplifying administration of the statute by requiring that all justifiable differentials be expressed in price would be inconsistent with this permission for "proportionally equal" differentials. 
granting of services is less likely to be detected than the granting of price differentials. ${ }^{59}$

In addition, the furnishing of services may in some circumstances be more appropriate than a price differential to pass on cost savings to a buyer. The furnishing of a "demonstrator" to the buyer, ${ }^{60}$ for example, would result in a benefit to the seller ${ }^{61}$ while at the same time providing a means of returning to the buyer the amount justified by cost savings. In any event, advertence to the fact of cost savings at the time a differential is granted does not appear to be a requirement for cost justification under Section 2(a) ${ }^{62}$ Thus prohibition of cost-justified, though disproportional, differentials in services or payments for services would disadvantage the seller with actual cost savings, and would therefore result in "disparity in the statutory consequences which attach to economically equivalent business practices." 63

${ }^{59}$ Although a payment for services, dealt with in Section 2(d), might be hidden from the public, no reason appears why the granting of a price differential could be more easily discovered.

${ }^{80} \mathrm{~A}$ "demonstrator" is a salesman whose services are furnished by the seller to the buyer. The "demonstrator" will perform the normal salesman's duties at the buyer's place of business, but will also take every opportunity to call the attention of the buyer's customers to the seller's product. See Elizabeth Arden, Inc. v. Gus Blass Co., 150 F.2d 988 (C.A.8th, 1945), cert. denied 326 U.S. 773 (1945). Thus, of two equal expenditures, that for providing services to the buyer may be of more benefit to the seller than would the granting of a price differential to the buyer.

${ }^{61}$ See discussion in the preceding note.

62 Although the furnishing of services has been said not to be on "proportionally equal" terms unless furnished according to a standard or program set up at the time the services were granted [see Elizabeth Arden, Inc. v. Gus Blass Co., 150 F.2d 988 (C.A.8th, 1945)], no similar holding with respect to cost justification has been found.

${ }^{63}$ Attorney General's Report 191 (1955).

\section{ACCORDING FULI FAITH AND CREDIT TO FOREIGN MODIFIABLE ALIMONY DECREES}

Limited recognition and enforcement of foreign modifiable alimony decrees often result in serious prejudice to a wife's $(W)^{1}$ right to installment payments where the husband $(\mathrm{H})$ has left the jurisdiction rendering the decree. ${ }^{2}$ Because the Full Faith and Credit Clause ${ }^{3}$ has been held to compel recognition only in

${ }^{1}$ For ease of reference, husband and wife will be designated by the symbols $H$ and $W$ respectively. The state awarding the alimony decree will be designated as F-1; the state in which enforcement of the decree is sought will be designated as F-2. "Foreign," as used in this Comment refers to sister states rather than foreign countries, and "alimony" includes support and separate maintainance.

2 See Jacobs, The Enforcement of Foreign Decrees for Alimony, 6 Law \& Contemp. Prob. 250 (1939).

${ }^{3}$ U.S. Const. Art. $4, \$ 1$. 